УДК 664.8.047:536.66

DOI https://doi.org/10.15673/swonaft.v85i1.2073

\title{
КОНВЕКТИВНЕ СУШІННЯ ЦУКРОВМІСНИХ ПАРЕНХІМНИХ ТКАНИН ДИНІ
}

\author{
Дмитренко Н.В., к.т.н., Шапар Р.О., к.т.н., с. н. с. \\ Інститут технічної теплофізики НАН України, м. Київ
}

В роботі наведено експериментальні дані щзодо особливостей сушіння паренхімних тканин дині, їх здатності до зв'язування води та теплових витрат на їх зневоднення. Представлено узагальнення кінетичних закономірностей вологообміну під час конвективного сушіння тканин дині у вигляді температурних кривих, кривих сушіння та швидкості сушіння. Показано, щчо процес видалення вологи проходить в періоді постійної та падаючої швидкостей. Обтрунтовано енергозберігаючі ступеневі режсми сушіння термолабільних тканин дині. Виявлено, щзо отримані дані щзодо динаміки зміни стану води в тканинах дині та кінетики зміни витрат теплоти на випаровування корелюють з критичними точками процесу сушіння. Зроблено висновок, що вже на початкових етапах сушіння відбувається видалення зв'язаної води з клатратних оболонок простих розчинних вуглеводів, які складають 78 \% сухих речовин дині, щчо зміна теплових витрат на зневоднення на початку сушіння відповідає зміні гідратачійної спроможності розчинних иукрів, а на наприкінці відбувається за класичними уявленнями щзодо сушіння колоїдних капілярно-пористих матеріалів. Піковий екзотермічний ефект в діапазоні досягнення тканинами дині вологості $37 . .27$ \% відносних ідентифіковано як процес кристалізаџї розчинних иукрів. Проведені дослідження виявили можливість одержання сушеноі дині із закристалізованими иукрами та суттєво підвищити якість і термін зберігання готового продукту.

Ключові слова: сушіння, диня, розчинні цукри, кристалізація.

Вступ. Економічно обгрунтоване становлення України на міжнародному ринку як агровиробника потребує створення надійних механізмів переробки сільськогосподарської сировини і доведення іiї до споживчої кондиції. Найбільш розповсюдженим та енерговитратним в технологіях переробки сільськогосподарської сировини є процес сушіння.

Формулювання проблеми та аналіз літературних джерел. Висушена диня використовується цілорічно у системі харчування як самостійний продукт або як складовий компонент у приготуванні різноманітних страв. Кліматичні умови східно-південних районів України сприятливі для вирощування плодів дині, але мало сприятливі для їх сушіння природним шляхом. Тож відпрацювання теплотехнологічних режимів сушіння дині є актуальним і перспективним напрямком, що обумовлений необхідністю якнайшвидшого перероблення плодів, через короткий термін їхнього зберігання, та проблемою накопичення нестандартної продукції і відходів дині у вигляді м'якоті, що залишається після видалення насіння.

М'якоть дини є суттєвою та цінною для нашого споживання частиною плода завдяки своєму унікальному складу (таблиця 1 [1, 2]). Цукри в дині представлені глюкозою, фруктозою і сахарозою. Харчова цінність дині посилюється наявністю кислот, ароматичних сполук, мінеральних речовин, вітамінів. Значна кількість фолієвої кислоти робить диню корисною в якості профілактичного засобу при атеросклерозі. Наявність значної кількості заліза дозволяє рекомендувати іiї для покращання кровотворення і нормалізації перебігу окислювальних процесів.

Таблиия 1

Середній хімічний склад плодів дині $[1,2]$

\begin{tabular}{|l|l|}
\hline \multicolumn{1}{|c|}{ Найменування показників } & \multicolumn{1}{|c|}{ Значення } \\
\hline Цукри, \% на сиру масу & $9 \ldots 18$ \\
\hline Ди- та моноцукри, \% до загальної кількості цукрів & \\
сахароза & 42,5 \\
глюкоза & 25,3 \\
фруктоза & 32,2 \\
\hline Пектинові речовини, \% на сиру масу & $0,4 \ldots 0,6$ \\
\hline Органічні кислоти, у перерахунку на переважну кислотність & $0,08 \ldots 0,2$ \\
\hline Вітаміни, мг/\% & \\
С & $20 \ldots 40$ \\
каротиноїди & $0,6 \ldots 0,8$ \\
\hline Мінеральні речовини (зола), \% на сиру масу & $0,4 \ldots 0,7$ \\
\hline Вода, \% на сиру масу & $82 \ldots 92$ \\
\hline Клітковина, \% на сиру масу & $0,4 \ldots 0,9$ \\
\hline
\end{tabular}


Як об’єкт сушіння диня є колоїдним капілярно-пористим матеріалом, що складається з різних за своєю структурою і складом частин. Вона має ніжну м'якоть, шкірку різного кольору та товщини, насіннєве гніздо 3 насінням у жорсткій оболонці. М'якоть побудована 3 крупних паренхімних клітин 3 міжклітинними проміжками. Кожна клітина оточена тонкою клітинною оболонкою всередині якої є протоплазма, а вакуолі заповнені клітинним соком з розчиненими речовинами: цукрами, розчинними формами пектинів і вітамінів, азотистими речовинами, кислотами, ферментами, мінеральними солями.

Основними вимогами, що пред'являються до процесу сушіння плодів дині, як і будь-якої іншої сільськогосподарської культури, $\epsilon$ інтенсивність, економічність, забезпечення максимально повного збереження природних властивостей вихідної сировини у кінцевій продукції. Експериментально встановлено, що зміна хімічних, біологічних і структурних властивостей рослинних тканин під час сушіння може

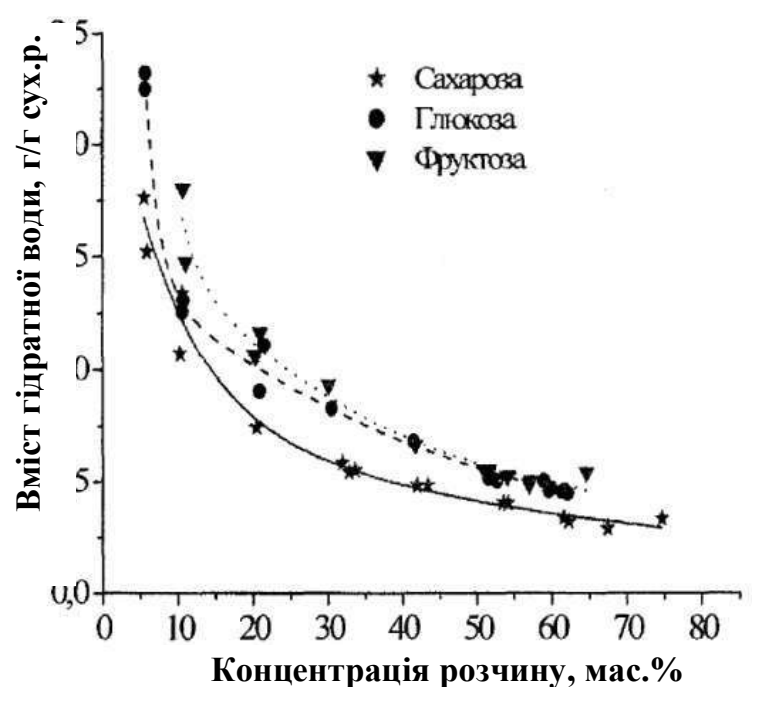

\section{Рис. 1 - Залежність питомого вмісту гідратної води в розчинах сахарози, $\alpha-D$-глюкози і} впливати на співвідношення вільної та зв'язаної води в них та теплоту зневоднення і залежить від тривалості, температурного рівня та інтенсивності теплової обробки. Фактором, що жорстко лімітує технологічні параметри сушіння рослин, є максимально допустима температура зневоднювального матеріалу. Теплотехнологічні фактори процесу сушіння впливають на тканини дині певним чином. Наявність у сировині термолабільних речовин робить плоди дині чутливими до впливу високих температур i обмежує температурний рівень процесу сушіння та можливість його прискорення завдяки підвищенню температури сушіння. Через довготривалість теплового впливу на зневоднювальний матеріал чиняться такі негативні явища, як карамелізація цукрів, утворення меланоїдинових сполук, руйнування вітамінного складу тощо, уникнення яких досягається сушінням дині в режимі конвективно-конденсаційного зневоднення [3, 4]. В міру видалення вологи 3 паренхімних тканин дині збільшується концентрація цукрів у клітинному соку, внаслідок чого також сповільнюється процес сушіння i зростають витрати теплоти на зневоднення.

Відомо, що збільшення концентрації сахарози у водному розчині призводить до зниження ступеня ії гідратації $[5,6,7]$, і ступінь її гідратації дещо залежить від температури [8]. Від концентрації водного розчину

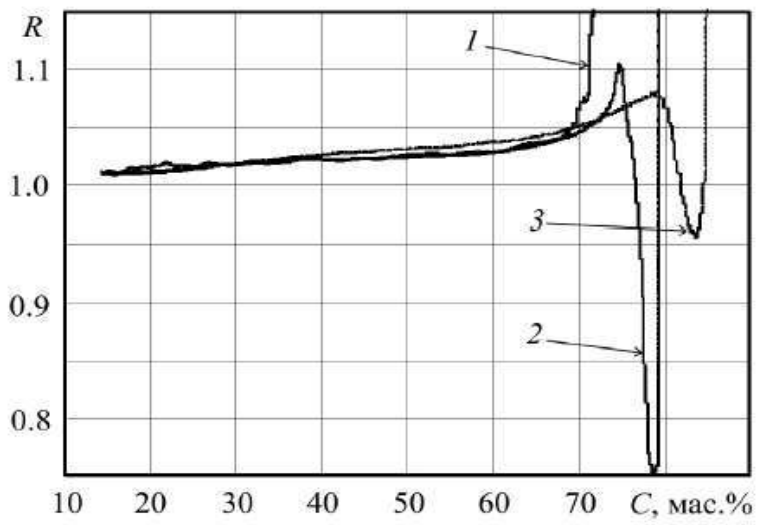

Рис. 2 - Криві залежності приведеної питомої теплоти випаровування води 3 розчинів сахарози від концентрації при температурі випарювання 40 (1), 60 (2) и $80^{\circ} \mathrm{C}(3)[12]$ залежить і ступень гідратації фруктози та глюкози [9]. Експериментальні данні свідчать про значне зменшення питомого вмісту гідратної (зв'язаної) води при збільшенні концентрації водного розчину цукрів 3 самого початку випарювання (рис.1 [9]). Характер залежності водоутримуючої здатності цукрів від концентрації водних розчинів свідчить про зміну кількості водневих зв'язків між молекулами цукрів та водою по мірі випарювання. Ця залежність безпосередньо впливає на водоутримуючу здатність, структурні зміни та процес сушіння цукровмісної рослинної сировини [10].

Спроба прояснити особливості зміни гідратаційної здатності сахарози у водному розчині шляхом теоретичного моделювання поведінки системи «водасахароза» [11] привели до висновку, що молекула води вставляється між глюкозою-2-О і фруктозою-1$\mathrm{OH}$ сахарози. Тобто виникає щось типу «містка» 3 молекули води між піранозним і фуранозним залишками сахарози. Ця молекула води є єдиною в межах першої гідратної оболонки сахарози, яка з'єднана з сахарозою двічі. Всі інші молекули води пов'язані з сахарозою тільки один раз - з їі гідроксилами. Важливим для нас результатом цієї роботи є розуміння, як процесу розчинення сахарози у воді, так і зворотної ії кристалізації в ході випарювання розчину. Процес випарювання води 3 концентрованого розчину сахарози можна уявити як агрегацію молекул сахарози в грона, що йде через заміну молекул води з гідратної оболонки гідроксилами інших молекул сахарози. Наступна кристалізація потребує вільного повороту піранозного залишку сахарози до фуранозного і може статися тільки після усунення молекули води, яка утворила жорсткий «містковий зв'язок». Але видалення молекули води, 
яка двічі зв'язана з молекулою сахарози та заблокована іншими молекулами сахарози всередині грона, є не такою легкою задачею. Тобто, отримав теоретичне пояснення давно відомий експериментальний факт утворення досить сильно пересичених концентрованих водних розчинів сахарози, що передують процесу ії кристалізації чи взагалі унеможливлюють його. На рис. 2 наведено приклад з роботи [12], де відображено таке утворення пересиченого розчину сахарози, яке повністю унеможливило процес ііі кристалізації при температурі випарювання $40^{\circ} \mathrm{C}$. Натомість, при температурах випарювання 60 та $80^{\circ} \mathrm{C}$ бачимо чіткі пікі екзотермічного процесу крісталізації сахарози.

Для нас важливо, що цукри, які дрібно закристалізувалися всередині висушених рослинних тканин, суттєво підвищують як смакові якості сушеного продукту, так і термін його зберігання. При відпрацюванні технологій отримання сушених продуктів 3 цукристих рослинних тканин іноді вдається, а іноді не вдається, отримати ефект кристалізації цукрів [13]. Зазвичай це залежить від складу цукрів, наявності чи відсутності цукрів, що легко кристалізуються, та технологічних параметрів режиму сушіння. Тканини дині мають значну кількість фруктози і глюкози, процес кристалізації яких не обтяжено наявністю «місткового зв'язку» через двічі зв'язану молекулу води, як у сахарози. Отже мета нашої роботи - відпрацювання технології отримання сушеної дині із закристалізованими цукрами

Матеріали та методи дослідження. Для дослідів використовували свіжі зрізи, завтовшки 1,5 ...2,5 мм, паренхімних тканин динь сортів «Титовка», «Валенсія».

Дослідження зміни кількості зв'язаної води в паренхімних тканинах дині при зневодненні було проведено на диференціальному сканувальному мікрокалориметрі ДСМ-2М. Для варіювання вологості зразки підсушували в потоці повітря 3 температурою $60{ }^{\circ} \mathrm{C}$ та швидкістю 3 м/с. Кількість зв'язаної води визначали за методикою [14] $з$ точністю не гірше $2 \%$.

Для встановлення закономірностей процесу сушіння дині були проведені досліди з кінетики конвективного зневоднення в елементарному шарі на експериментальному стенді з системою автоматичного збору та обробки інформації. Після встановлення певного режиму дослідження підготовлені зразки розміщували на піддоні робочої вимірювальної камери, вмикали комп'ютерну систему на основі розробленої програми "Sooshka", яка безперервно реєструє температуру сушильного агента впродовж досліду, виводить на екран зміну маси досліджуваного матеріалу під час видалення вологи та температуру зразка у координатах $m=f(\tau)$ та $t=f(\tau)$ відповідно. Програма дає змогу накопичувати інформацію про хід процесу сушіння, виконувати необхідні розрахунки та будувати графічні залежності у вигляді кінетики кривих сушіння та швидкості сушіння у координатах $W^{c}=f(\tau), d W^{c} / d \tau=f\left(W^{c}\right)[15]$.

Дослідження витрат теплоти на випаровування води з паренхімних тканин дині під час сушіння було проведено на диференціальному мікрокалориметрі випаровування ДМКИ-01 [16]. Прилад являє собою сукупність функціонально поєднаних теплового блоку, аналітичних терезів, компресора, блоку електронного керування і персонального комп'ютера з відповідним програмним забезпеченням. Ізотермічне конвективнокондуктивне сушіння відбувалось всередині калориметричної камери теплового блоку калориметра до моменту досягнення тканинами рівноважної з навколишнім середовищем вологості. Питому теплоту випаровування визначили 3 точністю не гірше $1 \%$, за методикою [17], шляхом синхронного виміру та покрокового співвідношення зміни маси матеріалу та кількості теплоти, що витрачена на випаровування.

Результати та їх обговорення. 3 результатів дослідів зміни кількості зв'язаної води в паренхімних тканинах дині при зневодненні за допомогою мікрокалоріметру ДСМ-2М (рис. 3) випливає, що видалення зв’язаної води з тканин дині розпочинається задовго до настання заключних етапів сушіння.

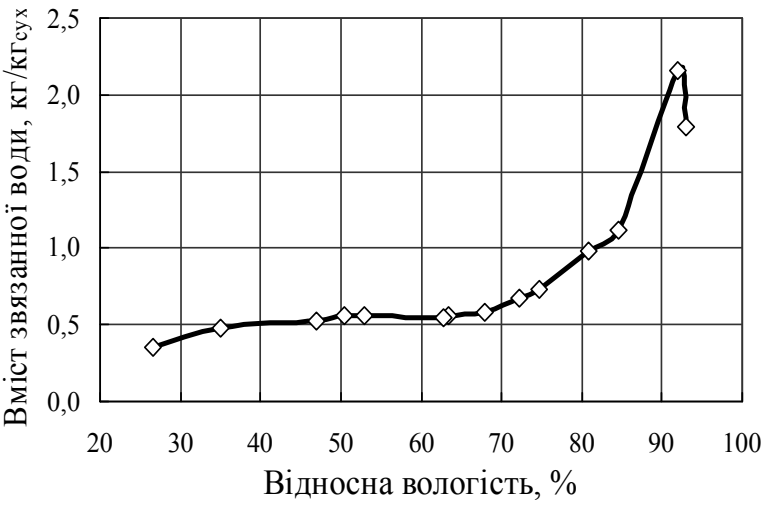

Рис. 3 - Залежність питомого вмісту зв'язаної води в паренхімних тканинах дині від вологості

На підгрунті аналізу результатів цих дослідів, що цілком відповідають літературним даним щодо зміни гідратаційної спроможності цукрів у розчинах (рис. 1), та аналізу хімічного вмісту тканин дині було зроблено висновок, що вже на початкових етапах сушіння відбувається видалення зв'язаної води з клатратних оболонок простих розчинних вуглеводів, які складають 78 \% сухих речовин дині.

Також, в даному експерименті, спостерігаємо деяке початкове підвищення питомого вмісту зв'язаної води в тканинах дині. В роботі [18] причиною подібного явища під час сушіння термооброблених паренхімних тканинах картоплі називають ентальпійно-ентропійний характер взаємодії води 3 компонентами сухих речовин - конкурування процесу тепломасообміну 3 процесом упорядкуваннярозупорядкування двох фаз матеріалу. Згідно [19] різке збігання тканин на перших етапах низькотемпературного конвективного сушіння може призводити до зменшення діаметру пор та міжклітинних проміжків. Це викликає таке зростання питомої кількості води, зв'язаної силами капілярного утримування, яке здатне ніве- 
лювати іiі зменшення через структурну деградацію нерозчинних біополімерів та зменшення кількості їх водоутримуючих центрів.

Припущення, що деяке початкове підвищення питомого вмісту зв'язаної води в тканинах дині відповідає етапу видалення 3 них лише вільної води, підтверджується результатами експериментальних досліджень процесу сушіння в режимі двостадійного зневоднення (рис. 4 [20]).

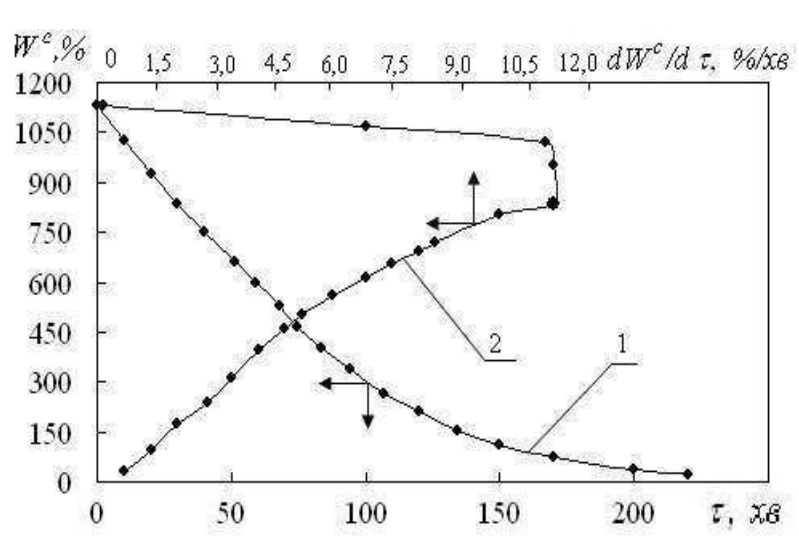

a)

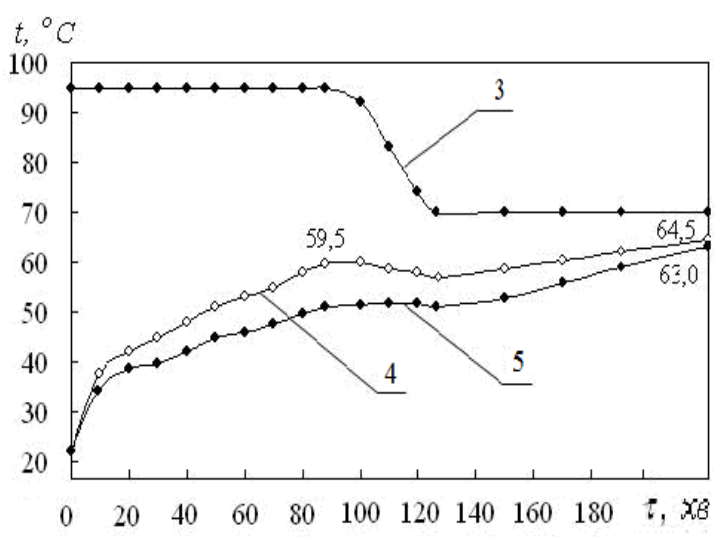

б)

1 -кінетика сушіння; 2 - швидкість сушіння; 3 -температура теплоносія; 4 - температура зовнішнього шару матеріалу; 5 - температура внутрішнього шару матеріалу.

Рис. 4 - Криві кінетики та швидкості (а) двостадійного конвективного сушіння дині, температури теплоносія і матеріалу (б) $\left(t=95 . .77^{\circ} \mathrm{C} ; V=2 \mathrm{M} / \mathrm{c} ; d=10\right.$ г/кг сухого повітря) [20]

Порівняльний аналіз кінетичних і швидкісних характеристик кінетики вологобміну при зазначених параметрах процесу доводить, що зневоднення дині дійсно проходить у періодах постійної (видалення лише вільної води) та падаючої швидкості. На стадії прогрівання швидкість сушіння збільшувалась до свого максимального значення 10,8 \%/хв і залишалася постійною до досягнення матеріалом величини критичної абсолютної вологості $W^{c}=835 \%$ ( $W=89 \%$ відносних), після чого швидкість зневоднення тканин дині поступово знижувалась (рис. 4 а). Використання високої температури на першій стадії позитивно впливає на кінетику вологообміну, інтенсифікуючи процес і скорочуючи його тривалість.

Використання стадійного режиму запобігає небажаним змінам у паренхімних тканинах дині та руйнування термолабільних речовин сировини, оскільки після досягнення матеріалом температури $59,5^{\circ} \mathrm{C}$ (рис. 4 б) температуру сушильного агента знижували від $95^{\circ} \mathrm{C}$ до $70{ }^{\circ} \mathrm{C}$ і підтримували іiі на такому рівні до кінця сушіння.

Результати дослідів зміни витрат теплоти на випаровування води протягом сушіння тканин дині за допомогою мікрокалориметра ДМКИ-01 представлено у координатах залежності питомих витрат теплоти на

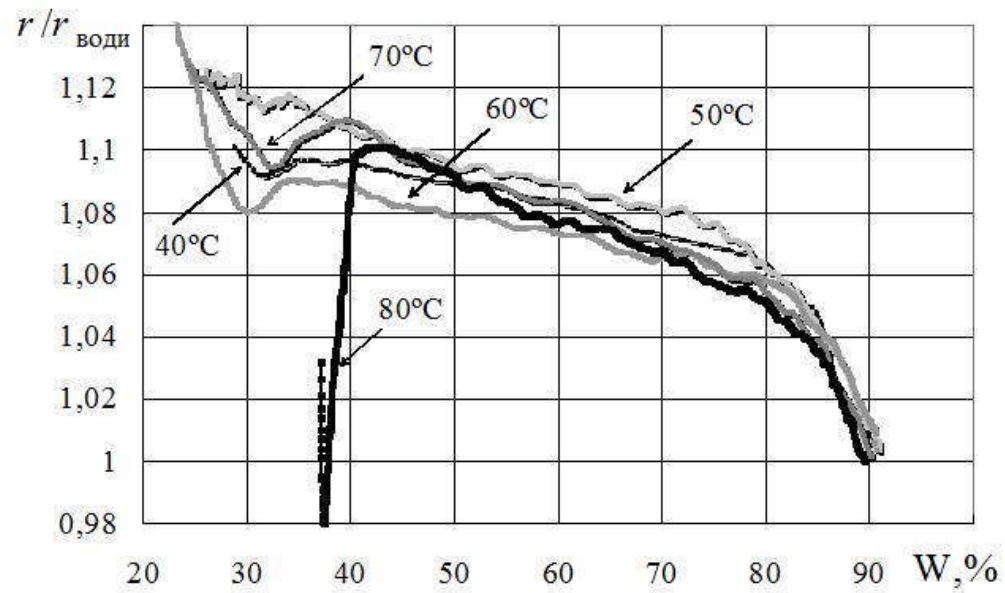

Рис. 5 - Залежності від відносної вологості приведеної питомої теплоти випаровування води 3 тканин дині при різних температурах сушіння $(V=0,8 \mathrm{~m} / \mathrm{c} ; d=4$ г/кг сухого повітря) випаровування, приведених до табличних для чистої води, від досягнутої тканинами відносної вологості (рис. 5).

Експериментально отримана питома теплота випаровування води 3 тканин дині починає зростати над теплотою випаровування чистої води $\left(r / r_{\text {води }}=1\right) 3$ самого початку вимірювання і перевищує табличні значення теплоти випаровування чистої води на $10 \ldots 12 \%$ наприкінці сушіння (рис. 5). Отриманий результат знаходиться цілком у відповідності до зміни теплових витрат на видалення води при випарюванні розчинів сахарози (рис. 2). Він відповідає і характеру зменшення кількості зв'язаної води в тканинах дині в міру їх висушування (рис. 3) та зростанню енергії зв'язування води у глибших гідратних шарах. 3більшення температури сушіння від 40 
до $80{ }^{\circ} \mathrm{C}$ мало вплинуло на отримані значення. Тобто, теплота випаровування води з тканин дині зменшується при підвищенні температури сушіння пропорційно зменшенню теплоти випаровування чистої води. Різке

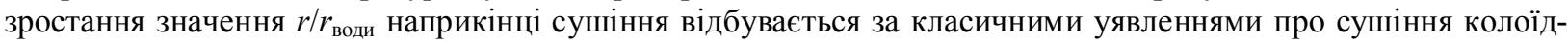
них капілярно-пористих матеріалів.

На кривих зміни витрат теплоти на випаровування спостерігається ще деякий піковий тепловий ефект в діапазоні досягнення тканинами вологості $37 . .27$ \% відносних (58...36 \% у абсолютних величинах). При збільшенні температури сушіння початок піку спочатку зсувається в бік меншої вологості тканин, а потім навпаки. Пікове зниження значення $r / r_{\text {води }}$ обумовлено накладанням на ендотермічний процес випаровування води якогось екзотермічного процесу. Найімовірніше - процесу кристалізації розчинних вуглеводів при концентруванні клітинного соку (рис. 2). Величина піку свідчить про меншу, або більшу частину цукрів, які закристалізувалися.

Дещо несподіваний для нас ефект різкого збільшення піку кристалізації цукрів в тканинах дині, сушених за температури $80^{\circ} \mathrm{C}$, можна пояснити більш значним перепадом температур та вологості вздовж шарів зразка при таких умовах сушіння. Це підтвержується і результатами сушіння, наведенними на рис. 4 б, більший перепад температур зовнішнього і внутрішнього шару тканин дині спостерегається при вищій температурі сушільного агенту.

\section{Висновки}

На підгрунті аналізу результатів дослідів зі зміни стану води в паренхімних тканинах дині при зневодненні та аналізу хімічного вмісту тканин дині було зроблено висновок, що вже на початкових етапах сушіння відбувається видалення зв'язаної води з клатратних оболонок простих розчинних вуглеводів, які складають $78 \%$ сухих речовин дині.

Аналіз результатів дослідження витрат теплоті на випаровування при сушінні паренхімних тканин дині дозволяє стверджувати, що їх зміна на початку процесу відповідає зміні гідратаційної спроможності розчинних цукрів та зміні теплових витрат на зневоднення їх розчинів, а на наприкінці сушіння відбувається за класичними уявленнями щодо сушіння колоїдних капілярно-пористих матеріалів.

Піковий екзотермічний ефект в діапазоні досягнення тканинами дині вологості $37 . .27$ \% відносних, який корелює з наявними даними щодо процесу кристалізації цукрів у розчинах, було ідентифіковано нами, як процес кристалізації цукрів дині.

Отримані висновки калориметричних експеріментів добре співпали з результатами конвективного сушіння паренхімних тканин дині.

Отже, проведені дослідження та отримані результати підтверджують наше припущення щодо можливості одержання сушеної дині зі закристалізованими цукрами i, тим самим, суттєво підвищити якість та термін зберігання готового продукту.

\section{References}

1. Dynia: khimichnyi sklad, kaloriinist, korysni vlastyvosti [Melon: chemical composition, caloric content, useful properties.]. (2021, may, 7). Retrieved from https://dovidka.biz.ua/dinya-himichniy-sklad-kaloriynist-korisnivlastivosti/ (In Ukrainian).

2. Skurikhina, I. M., Volgareva, M. N. (1987). Khimicheskiy sostav pishchevykh produktov: Spravochnye tablitsy [Chemical composition of food products: Reference tables], 2 vol. Moscow: Agropromizdat. (In Russian).

3. Sniezhkin, Yu.F., Shapar, R.O. (25.11.2013). Patent 103864, MPK A23B 7/02. Sposib vyrobnytstva sushenoi dyni [Dried melon production method]. a201302965; declared 11.03.2013, Bulletin No 22. (In Ukrainian).

4. Snezhkin, Yu.F., Shapar, R.A., Gusarova, E.V. (2016). Energoeffektivnyy konvektivno-kondensatsionnyy metod sushki v tekhnologiyakh proizvodstva chipsov [Energy-efficient convective-condensation drying method in chip production technologies]. Povysheniye effektivnosti protsessov i apparatov v khimicheskoy $\mathrm{i}$ smezhnykh otraslyakh promyshlennosti:. Procedings of international conference dedicated to the 105-th anniversary of the birth of A.N. Planovsky. (Sept. 8-9, 2016, Moscow). (T.2., pp. 45-47). (In Russian).

5. Pasynskiy, A. G. (1946). Solvatatsiya neyelektrolitov i szhimayemost ikh rastvorov [Solvation of nonelectrolytes and compressibility of their solutions]. Zhurnal fizicheskoy khimii, 20(9), 981-994. (In Russian).

6. Kharin, S. E., Kniga, A. A. (1963). O vodno-sakharnykh rastvorakh [About water-sugar solutions]. Izv. vuzov. Pishchevaya tekhnologiya, 5, 47-51. (In Russian).

7. Mikhaylik V.A. (2006). Eksperimentalnoe issledovanie gidratatsii sakharozy [Experimental study of sucrose hydration]. Naukovi pratsi Odeskoï natsionalnoï akademï kharchovikh tekhnologiy, 28(2), 370-374. (In Russian).

8. Buravleva, V. I., Zubchsnko, A. V., Oleynikova, A. Ya. (1977). K voprosu o gidratatsii Sakharov [On the issue of sugar hydration.]. Izv. vuzov. Pishchevaya tekhnologiya, 5, 129-131. (In Russian).

9. Mikhaylik, V.A. (2008). Osobennosti povedeniya rastvorov sakharov pri obezvozhivanii [Features of the behavior of sugar solutions during dehydration]. Sovremennye energosberegayushchiye teplovyye tekhnologii. Procedings of 3th of international conference (Sept. 16-30, 2008, Moscow-Tambov). (pp. 240-242). (In Russian). 
10. Dmytrenko, N.V. (2018). Vplyv rozchynnykh rechovyn na stan vody v roslynnykh tkanynakh ta kinetyku yikh sushinnia [Effect of soluble substances on the state of water in plant tissues and their drying kinetics]. Scientific Works, 82(1). https://doi.org/10.15673/swonaft.v82i1.1015 (In Ukrainian).

11. Frieder W. Lichtenthaler, Peter Pokinskyj, Stefan Immel. (1996). Saccharose als nachwachsender organischer Rohstoff: Neue, selektive Einstiegsreaktionen via Computersimulation ihrer Lösungskonformationen und der Reaktivität ihrer Hydroxylgruppen. Zuckerind. V. 121(3), 174-190.

12. Mikhaylik, V. A., Dmitrenko, N. V., Snezhkin, Yu. F. (2019). Issledovaniye vliyaniya gidratatsii na teplotu ispareniya vody iz rastvorov sakharozy [Investigation of the effect of hydration on the heat of evaporation of water from sucrose solutions]. Inzhenerno-fizicheskiy zhurnal, 92 (4), 945-952. (In Russian).

13. Mykhailyk, V.A., Sniezhkin, Yu.F., Korinchevska, T.V., Hornikov, Yu.I. (2015). Vplyv rezhymu konvektyvnoho sushinnia na krystalichnist poroshkiv z yabluk ta tsukrovoho buriaku [Effect of convective drying mode on the crystallinity of apple and sugar beet powders]. Prom. teplotekhnyka, 37(5). https://doi.org/10.31472/ihe.5.2015.03 (In Ukrainian).

14. Deodar, S., Lunsr, F. (1984). Izmereniye soderzhaniya svyazannoy (nezamerzayushchey) vody metodom differentsialnoy skaniruyushchey kalorimetrii [Measurement of the content of bound (non-freezing) water by differential scanning calorimetry]. Voda v polimerakh. Pod red. S. Roulenda. Per. s angl. Moscow: Mir. (pp. 273-287). (In Russian).

15. Sniezhkin, Yu.F., Shapar, R.O. (2018). Teplomasoobminni tekhnolohii pererobky pektynovmisnoi syrovyny [Heat and mass transfer technologies for processing pectin-containing raw materials]. Kyiv: Sik Hrup Ukraina. (In Ukrainian).

16. Sniezhkin, Yu.F., Dekusha, L.V., Dubovikova, N.S., Hryshchenko, T.H., Vorobiov, L.I., Boriak, L.A. (2008). Patent 84075, MPK G01 N25/26, G01 N25/28. Kalorymetrychnyi prystrii dlia vyznachennia pytomoi teploty vyparovuvannia volohy i orhanichnykh ridyn $\mathrm{z}$ materialiv [Calorimetric device for determining the specific heat of evaporation of moisture and organic liquids from materials]. a200613266, declared 15.12.2006, Bulletin No 17. (In Ukrainian).

17. Dubovikova, N.S., Snezhkin, Yu.F., Dekusha, L.V., Vorobyev, L.I. (2013). Teplometricheskiy pribor sinkhronnogo termicheskogo analiza dlya opredeleniya udelnoy teploty ispareniya [A thermometric device of synchronous thermal analysis for determining the specific heat of evaporation.]. Prom. Teplotekhnika, 25(2), 87-95. (In Russian).

18. Grishin, M.A., Pogozhikh, N.I., Potapov, V.A. (2001). Effekt dinamicheskogo strukturirovaniya vlagi v protsesse sushki [The effect of dynamic structuring of moisture in the drying process. Industrial heat engineering]. Prom. Teplotekhnika, 23(4-5), 100-105. (In Russian).

19. Potapov, V.A. (2004). Kinetika sushki: analiz i upravleniye protsessom [Drying kinetics: process analysis and control]. Kharkov: KhGUPT. (In Russian).

20. Sniezhkin, Yu.F., Shapar, R.O. (2013). Obgruntuvannia rezhymiv sushinnia dyni [Justification of melon drying modes]. Naukovi pratsi Odeskoï natsionalnoï akademiï kharchovikh tekhnologiy, 43(2), 102-104. (In Ukrainian).

\title{
CONVECTIVE DRYING OF SUGAR-CONTAINING MELON PARENCHYMAL TISSUES
}

\author{
Dmytrenko N. V., Shapar R.O. \\ Institute of Engineering Thermophysics of the National Academy of Sciences of Ukraine, Kyiv
}

The article represents experimental data on the peculiarities of drying of melon parenchymal tissues, on their ability to bind water, on the heat consumption for their dehydration. The generalization of kinetic regularities of moisture exchange during convective drying of melon tissues in the form of temperature curves, drying curves and drying speed curves is presented. It is shown that the process of moisture removal occurs in periods of constant and falling speed. Energy - saving step modes of drying of thermolabile melon tissues are substantiated. The results of calorimetric experiments coincided well with the results of convective drying of melon tissues. It was found that the data on the dynamics of changes in the state of water in melon tissues and the kinetics of changes in heat consumption for evaporation correlate with the decisive points of the drying process. It is concluded that bound water from clathrate shells of simple soluble carbohydrates (which make up $\sim 78 \%$ of melon dry matter) is removed already in the opening stages of drying but the removal of water at the final stage is according to the classical ideas of drying colloidal capillary-porous materials. Some initial increase in the specific content of bound water in melon tissues correlates with the stage of constant drying speed. The analysis of heat consumption for evaporation allows us to state that the change in consumption correlates with the change in the hydration capacity of soluble melon sugars and with the change in heat consumption for dehydration of sugar solutions. The peak exothermic effect, which is in the range of melon tissue moisture 37 ... $27 \%$ relative, has been identified as a process of crystallization of soluble 
sugars. Studies have shown the possibility of obtaining dried melon with crystallized sugars and significantly improve the quality and shelf life of the finished product.

Keywords: drying, melon, soluble sugars, crystallization.

\section{Список використаної літератури}

1. Диня: хімічний склад, калорійність, корисні властивості. [Електронний pecypc]. URL: https://dovidka.biz.ua/dinya-himichniy-sklad-kaloriynist-korisni-vlastivosti (дата звернення 07.05. 2021).

2. Скурихина, И. М., Волгарева, М. Н. Химический состав пищевых продуктов: справ. таблицы. Кн. 2. Москва: Агропромиздат, 1987. $360 \mathrm{c}$.

3. Пат. 103864, Україна, МПК А23В 7/02, F26B 3/06. Спосіб виробництва сушеної дині / Ю.Ф. Снєжкін, Р.О. Шапар. заявл. 11.03.2013; опубл. 25.11.2013 р. Бюл. №22.

4. Снежкин, Ю.Ф., Шапар, Р.А., Гусарова, Е.В. Энергоэффективный конвективно-конденсационный метод сушки в технологиях производства чипсов. Повышение эффективности процессов и аппаратов в химической и смежных отраслях промышленности : труды междунар. н.-т. конф. посвященной 105летию со дня рождения А.Н.Плановского. Москва, Россия, 8-9 сентября 2016. Т.2. С. 45-47.

5. Пасынский, А. Г. Сольватация неелектролитов и сжимаемость их растворов. Журнал физической химии. 1946. Т. 20, № 9. С. 981-994.

6. Харин, С. Е., Книга, А. А. О водно-сахарных растворах. Изв. вузов. Пищевая технология. 1963. № 5. С. $47-51$.

7. Михайлик, В. А. Экспериментальное исследование гидратации сахарозы. Наукові пращиі ОНАХТ. Одеса, 2006. Вип. 28, т.2. С. 370-374.

8. Буравлева, В. И., Зубчснко, А. В., Олейникова, А. Я. К вопросу о гидратации сахаров. Изв. вузов. Пищевая технология. 1977. № 5. С. 129-131.

9. Михайлик, В.А. Особенности поведения растворов сахаров при обезвоживании. Современные энергосберегающие тепловые технологии. СЭТТ-2008: труды III Международной науч.-практ. конференции. Москва-Тамбов, 16-20 сент. 2008. Т. 1. С.240-242.

10. Дмитренко, Н.В. Вплив розчинних речовин на стан води в рослинних тканинах та кінетику їх сушіння. Наукові праиі ОНАХТ. Одеса, 2018. Т. 82, вип. 1. С. 102-108.

11. Frieder W. Lichtenthaler, Peter Pokinskyj, Stefan Immel. Saccharose als nachwachsender organischer Rohstoff: Neue, selektive Einstiegsreaktionen via Computersimulation ihrer Lösungskonformationen und der Reaktivität ihrer Hydroxylgruppen. Zuckerind. 1996. Vol. 121, No. 3. S. 174-190.

12. Михайлик, В. А., Дмитренко, Н. В. Снежкин, Ю. Ф. Исследование влияния гидратации на теплоту испарения воды из растворов сахарозы. Инженерно-физический журнал. 2019. Т. 92, № 4. С. 945-952.

13. Михайлик, В.А. Снєжкін, Ю.Ф., Корінчевська, Т.В., Горніков, Ю.І. Вплив режиму конвективного сушіння на кристалічність порошків з яблук та цукрового буряку. Промыщленная теплотехника. 2015. Т. 37, № 5. С. 23-37.

14. Деодар, С., Лунср, Ф. Измерение содержания связанной (незамерзающей) воды методом дифференциальной сканирующей калориметрии. Вода в полимерах. Под ред. С. Роуленда. Пер. с англ. М.: Мир, 1984. C. $273-287$.

15. Снєжкін, Ю.Ф. Шапар, Р. О. Тепломасообмінні технології переробки пектиновмісної сировини. Київ: Сік Груп Україна, 2018. 228 с. ISBN 978-617-7457-69-4.

16. Пат. 84075, Україна МПК G01 N25/26, G01 N25/28 . Калориметричний пристрій для визначення питомої теплоти випаровування вологи і органічних рідин з матеріалів / Ю.Ф. Снєжкін, Л.В. Декуша, Н.С. Дубовікова, Т.Г. Грищенко, Л.Й. Воробйов, Л.А. Боряк. Заявка № а2006 13266 від 15.12.2006

17. Дубовикова, Н.С., Снежкин, Ю.Ф., Декуша, Л.В., Воробьев, Л.И. Теплометрический прибор синхронного термического анализа для определения удельной теплоты испарения. Промышиленная теплотехника. 2013. Т. 25, № 2. С. 87-95.

18. Гришин, М.А. Погожих, Н.И., Потапов, В.А. Эффект динамического структурирования влаги в процессе сушки. Промышиленная теплотехника. 2001. Т. 23, №. 4-5. С. 100-105.

19. Потапов, В.А. Кинетика сушки: анализ и управление процессом. Харьков: ХГУПТ, 2009. 250 с.

20. Снєжкін, Ю.Ф., Шапар, Р.О. Обгрунтування режимів сушіння дині. Наукові праці ОНАХТ. Одеса: 2013. Вип.43, т. 2._С. 102-104. Режим доступу: http://nbuv.gov.ua/UJRN/Np_2013_43(2)_26.

Отримано в редакцію 31.03 .2021

Прийнято до друку 22.06.2021
Received 31.03.2021

Approved 22.06.2021 